Volume 11 Number 2 November 2021 Page. 1-6

Journal Homepage : http://teknois.stikombinaniaga.ac.id/index.php/JBS

DOI Link : http://doi.org/10.36350/jbs.v11i2

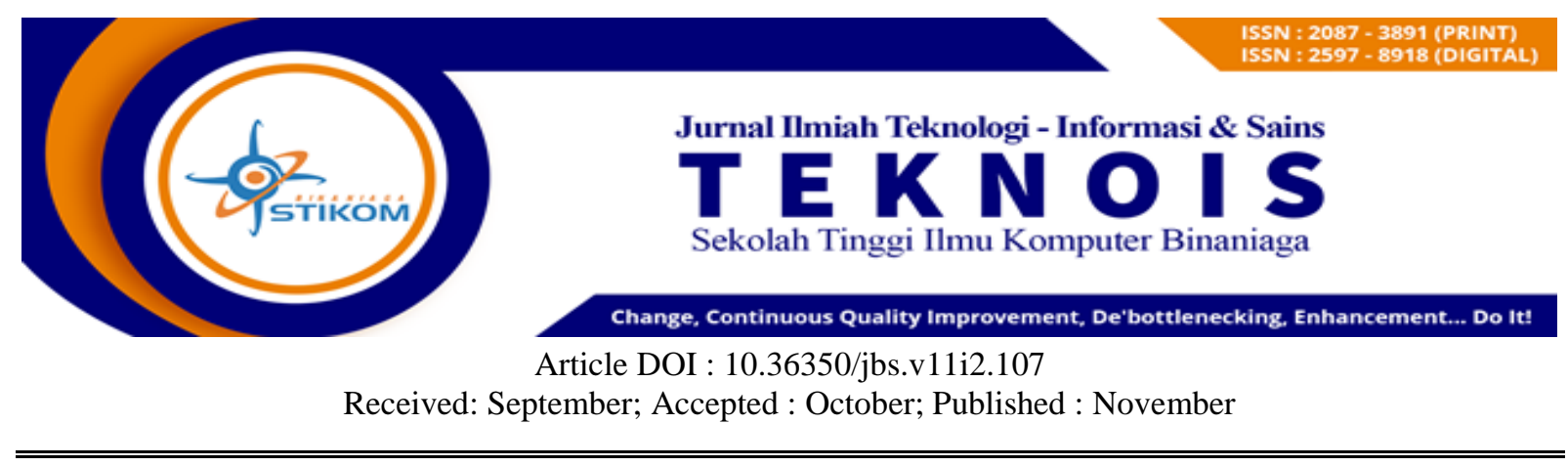

\title{
Menelisik Platform Digital Dalam Teknologi Bahasa Pemrograman
}

\author{
Dea Nur Zuraidah ${ }^{1 *}$, Muhammad Fajar Apriyadi², Ahmad Rizal Fatoni ${ }^{3}$ \\ Muhammad Al Fatih ${ }^{4}$, Yusuf Amrozi ${ }^{5}$ \\ ${ }^{1}$ Sistem Informasi/Universitas Islam Negeri Sunan Ampel Surabaya \\ Email: h96218056@ student.uinsby.ac.id \\ ${ }^{2}$ Sistem Informasi/Universitas Islam Negeri Sunan Ampel Surabaya \\ Email: 09010620009@ student.uinsby.ac.id \\ ${ }^{3}$ Sistem Informasi/Universitas Islam Negeri Sunan Ampel Surabaya \\ Email: 09020620019@ student.uinsby.ac.id \\ ${ }^{4}$ Sistem Informasi/Universitas Islam Negeri Sunan Ampel Surabaya \\ Email: 09020620034@ student.uinsby.ac.id \\ ${ }^{5}$ Sistem Informasi/Universitas Islam Negeri Sunan Ampel Surabaya \\ Email: yusuf.amrozi@uinsby.ac.id
}

\begin{abstract}
This study aims to identify the role of programing languages in building or developing a digital platform in accordance with the specifications of the needs desired by the community or users of the digital platform. The methodology of qualitative data description and literature study by Seeking information from various literatures and reference source related to the topics discussed. The data obtained is then analyzed and then concluded "so that result are obtained" from the topic. From this research, it can be concluded that programming languages play an important role in the development of a digital platform from browser, social media, to digital platform used for education.
\end{abstract}

Keywords: Digital Platform; Programing Language; Information System; qualitative; social media.

\section{ABSTRAK}

Penelitian ini bertujuan untuk mengidentifikasi peran bahasa pemrograman dalam membangun atau mengembangkan platform digital sesuai dengan spesifikasi kebutuhan yang diinginkan oleh masyarakat atau pengguna digital platform. Metode yang digunakan dalam penelitian ini adalah metode uraian data kualitatif dan studi literatur dengan mencari informasi dari berbagai literatur dan sumber-sumber referensi yang berkaitan dengan topik yang dibahas. Data yang diperoleh kemudian dianalisis dan kemudian disimpulkan "sehingga didapatkan hasil" dari topik tersebut. Dari penelitian ini dapat disimpulkan bahwa bahasa pemrograman sangat berperan penting dalam perkembangan dari suatu platform digital dari mulai browser, sosial media, hingga platfrom digital yang digunakan untuk pendidikan.

Keywords: Digotal platform; Bahasa Pemrograman; Sistem Informasi; Kualitatif; social Media.

\section{A. PENDAHULUAN}

\section{Latar Belakang}


Di era digitalisasi saat ini, platform digital menjadi suatu kebutuhan bagi masyarakat. Pandemi Covid-19 mengharuskan kita untuk membatasi lingkungan sosial kita yang sebelumnya dapat dengan mudah keluar atau berkunjung ke tempat umum namun sekarang hal itu harus dihindari. Sekarang hampir semua masyarakat sudah mulai atau sudah terbiasa menggunakan digital platform baik untuk belanja online, meeting online atau belajar online. Semua kegiatan itu sekarang dilakukan online karena memang saat ini hal itu sangat memudahkan masyarakat.

Digital platform merupakan suatu media berbasis digital yang bertujuan untuk memudahkan kehidupan masyarakat di saat ini. Banyak platform digital yang digunakan oleh hampir semua masyarakat bahkan menjadi sebuah kebiasaan atau keseharian, misalnya platform social media seperti Facebook, Instagram, dan WhatsApp. Ketiga platform tersebut telah digunakan oleh hampir semua masyarakat Indonesia untuk keperluan sehari-hari. Selain itu, platform tersebut memiliki aksesnya yang mudah untuk berbagi informasi secara cepat. Contoh yang lainnya ialah Tokopedia, Shopee, dan Lazada yang merupakan tempat atau platform belanja online yang saat ini namanya sangat besar di Indonesia bahkan hingga di Asia. Di zaman sekarang, belanja atau berjualan online menjadi suatu kebiasaan yang sedang digandrungi oleh masyarakat.

Penggunaan dari digital platform juga membawa banyak dampak positif dan negatif. E-Commerce dapat membantu seseorang untuk mengembangkan usaha dengan melakukan jual beli tanpa harus keluar biaya untuk membayar tempat sewa, lalu di bidang pendidikan apalagi di era covid-19 saat ini para murid dan guru diharuskan untuk belajar menggunakan aplikasi seperti Zoom, Google classroom, Google meet dan semacamnya, lalu misal pencarian informasi sangat mudah dikarenakan google ataupun sosial media bahkan tidak jarang kita atau bahkan badan milik negara seperti kepolisian mencari informasi lewat sosial media. Dampak negatif yang ditimbulkan antara lain banyaknya penipuan di media sosial, hoax, dan cyber crime namun, dibalik itu semua dampak positif dari penggunaan digital platform tidak kalah banyak misal dari segi fungsionalitas aplikasi yang dapat mempermudah pekerjaan manusia.

Dibalik perkembangan digital platform yang sangat cepat ada teknologi yang digunakan untuk bisa menciptakan suatu media yang canggih dan efisien yaitu bahasa pemrograman itu sendiri. Dikutip dari jurnal (Saragih, 2016) bahasa pemrograman, atau sering diistilahkan juga dengan bahasa komputer atau bahasa pemrograman komputer adalah suatu bahasa yang dirancang oleh manusia sedemikian rupa hingga akhirnya computer tersebut bisa melakukan suatu perintah. Bahasa ini memungkinkan seorang programmer dapat menentukan secara persis data mana yang akan diolah oleh komputer, bagaimana data ini akan disimpan/diteruskan, dan jenis langkah apa secara persis yang akan diambil dalam berbagai situasi.

Bahasa pemrograman saat ini telah berkembang pesat dan telah banyak membantu masyarakat untuk membuat sesuatu secara sistematis, dan begitu juga dengan perkembangan jenisnya yang semakin banyak, contohnya seperti Java, Java script, $\mathrm{C}++, \mathrm{C}$, python, PHP, JSP, ASP, Pascal, MySQL dan masih banyak lagi. Dengan adanya berbagai macam jenis bahasa pemrograman tentunya ini akan menambah inovasi-inovasi atau fitur-fitur canggih untuk kedepannya di dalam digital platform.

Dengan kehadiran bahasa pemrograman pembuatan digital platform juga akan menambah berbagai macam fitur canggih dan efisien bagi para customer dan pengembang dari platform itu sendiri, contohnya saat ini hampir semua digital platform menggunakan database untuk menampilkan dan menyimpan informasi dari 
customer atau pengguna platform tersebut, hal ini dikarenakan dari bahasa pemrograman yang bisa memungkinkan tim pengembang atau perusahaan yang mengelolah suatu platform untuk mengakses berbagai macam informasi atau data yang penting.

\section{Tujuan}

Adapun tujuan dari penelitian ini adalah untuk menelisik peran bahasa pemrograman dalam membanguan atau mengembangkan platform digital sesuai dengan spesifikasi kebutuhan yang diinginkan oleh masyarakat atau pengguna digital platform

\section{B. METODE}

Artikel ini dihasilkan dengan menggunakan metode penelitian deskriptif kualitatif yang berupa uraian data kualitatif dari studi literatur. Dengan mencari informasi dari berbagai literatur dan sumber-sumber referensi yang berkaitan dengan topik yang dibahas. Data yang diperoleh dianalisis dan kemudian disimpulkan "sehingga didapatkan hasil" dari topik penelitian tersebut.

\section{HASIL DAN PEMBAHASAN}

\section{Sistem informasi}

Menurut Jogiyanto (2005:36), sistem informasi adalah suatu sistem didalam suatu organisasi yang mempertemukan kebutuhan pengolahan transaksi harian, mendukung operasi,bersifat manajerial dan kegiatan strategi dari suatu organisasi yang menyediakan pihak luar tertentu dengan laporan - laporan yang diperlukan.(Cahyaningtyas \& Iriyani, 2015).

Menurut Kodir (2008:7), sistem informasi merupakan sebuah kombinasi antara prosedur kerja, informasi, orang, dan teknologi informasi yang diorganisasikan untuk mencapai tujuan yang sama dalam sebuah organisasi. Sistem informasi selalu menggambarkan, merancang, mengimplementasikan dengan menggunakan proses perkembangan sistematis dan merancang sebuah sistem informasi berdasarkan analisa kebutuhan. Jadi bagian utama dari proses ini adalah mengetahui rancangan analisis sistem. Seluruh aktivitas utama dilibatkan dalam siklus perkembangan yang lengkap. Siklus perkembangan sistem informasi memiliki tahapan antara lain yaitu : Pemeriksaan, Analisis, Rancangan, Mengimplementasikan, dan Pemeliharaan.(Hermawan et al., 2016).

Dari pendapat para ahli diatas bisa disimpulkan bahwa sistem merupakan perangkat atau bagian yang saling berkaitan dan beroperasi bersama untuk mengoperasikan data pada waktu tertentu untuk menghasilkan informasi atau energi.

\section{Jenis - jenis Bahasa Pemrograman}

Menurut Saragih dalam jurnalnya bahasa pemrograman adalah sebuah instruksi standar untuk memerintah komputer agar menjalankan perintah tertentu bahasa pemrograman ini merupakan suatu himpunan dari aturan sintaks dan semantik yang dipakai untuk mendefinisikan program komputer, bagaimana data ini disimpan/diteruskan dan jenis langkah apa secara persis yang akan diambil dalam berbagai situasi(Saragih, 2016).

Adapun macam - macam contoh bahasa pemrograman:

a. Bahasa pemrograman PHP

Bahasa pemrograman script server-side yang didesain untuk pengembangan web.

Selain itu PHP juga bisa digunakan sebagai bahasa pemrograman umum. PHP di kembangkan pada tahun 1995 oleh Rasmus Lerdorf, dan sekarang dikelola oleh The PHP Group. PHP digunakan untuk membuat halaman web pribadi. Dalam beberapa tahun perkembangannya, PHP berubah menjadi bahasa pemrograman yang sangat luar biasa dan banyak digunakan oleh website - website besar.

b. Bahasa pemrograman JSP 
Volume 11 Number 2 November 2021 Page. 1-6

Journal Homepage : http://teknois.stikombinaniaga.ac.id/index.php/JBS

DOI Link : http://doi.org/10.36350/jbs.v11i2

Java Server Pages (JSP), suatu teknologi web berbasis bahasa pemrograman java dan berjalan pada platform java. JSP dapat berupa gabungan antara basis html dan fungsi - fungsi dari JSP itu sendiri. Teknologi JSP menyediakan cara yang lebih mudah dan cepat dalam membuat halaman - halaman web yang menampilkan isi secara dinamik dan bekerja dengan berbagai macam web server.

JSP adalah bahasa scripting untuk web programming yang bersifat server side seperti halnya PHP dan ASP. Berbeda dengan servlet, JSP tidak perlu melakukan kompilasi terlebih dahulu sebelum dijalankan, tetapi server yang akan melakukan tugas tersebut.

c. Bahasa pemrograman ASP

ASP (active server pages) merupakan salah satu bahasa pemrograman web untuk membuat halaman web yang dinamis. ASP merupakan salah satu produk teknologi yang disediakan oleh Microsoft. ASP diproses melalui web server dan hasil proses ini menghasilkan HTML yang akan dikirimkan melalui penjelajah web.

Bahasa ASP murni Object Oriented Programming (OOP) memiliki struktur bahasa yang sama dengan bahasa visual basic yang mudah dimengerti karena sintaksnya menggunakan bahasa inggris. Seperti diketahui bahwa visual basic adalah bahasa pemrograman yang paling mudah dimengerti dan dipelajari dibandingkan bahasa pemrograman lainnya. Oleh karena itu ASP sangat mudah dipelajari oleh para pemula sekalipun untuk membuat aplikasi web.

d. Bahasa pemrograman $\mathrm{C}$

Sebuah bahasa pemrograman komputer yang bisa digunakan untuk membuat berbagai aplikasi seperti Windows dan Linux, hingga compiler untuk bahasa pemrograman, dimana $\mathrm{C}$ banyak digunakan untuk membuat bahasa pemrograman lain yang salah satunya adalah PHP.

Dengan bahasa $\mathrm{C}$ inilah sistem operasi UNIX ditulis ulang. Pada gilirannya, UNIX menjadi dasar dari banyak sistem operasi modern saat ini, temasuk Linux, Mac OS (IOS), hingga sistem operasi Android.

e. Bahasa pemrograman Python

Python adalah bahasa pemrograman interpretatif multiguna dengan filosofi perancangan yang berfokus pada tingkat keterbacaan kode. Python diklaim sebagai bahasa yang menggabungkan kapabilitas, kemampuan, dengan sintaksis kode yang sangat jelas, dan dilengkapi dengan fungsionalitas pustaka standar yang besar serta komprehensif.

Python merupakan salah satu bahasa pemrograman tingkat tinggi (high level language). Python dirancang untuk memberikan kemudahan bagi programmer melalui segi efisiensi waktu, kemudahan dalam pengembangan dan kompatibilitas dengan sistem. Python bisa digunakan untuk membuat aplikasi standalone (berdiri sendiri) dan pemrograman script.

\section{Platform digital}

Dalam kamus besar bahasa Indonesia (KBBI) platform diartikan sebagai sebuah program, rencana kerja, sebuah pernyataan dari kelompok partai tentang program kebijakan, sampai dengan mimbar, pentas, atau panggung. (Platform @ Kbbi.Web.Id, n.d.)

Digital Platform merupakan suatu media yang berbasis digital. Banyak sekali platform digital saat ini yang sudah menjadi kebiasaan atau keseharian masyarakat disekitar kita untuk menggunakannya, misalnya platform social media seperti Facebook, Instagram, dan WhatsApp mereka adalah tiga platform yang bahkan hampir semua masyarakat Indonesia untuk menggunakannya dikarenakan aksesnya yang mudah dan membantu untuk berbagi informasi secara cepat. Lalu misal ada Tokopedia, Shopee, dan Lazada 
adalah tempat atau platform belanja online yang saat ini namanya sangat besar di Indonesia bahkan hingga di Asia, di zaman sekarang bahkan beberapa orang sudah bukan lagi bisa mencoba belanja atau berjualan online tapi mereka sudah harus wajib untuk bisa berbelanja atau berjualan online.

Penggunaan dari digital platform juga membawa banyak dampak antara negatif dan positif banyaknya penipuan di media sosial, hoax, dan cyber crime namun dibalik itu semua dampak positif dari penggunaan digital platform tidak kalah banyak misal dari segi ekonomi aplikasi E-Commerce sangat membantu menambah peluang usaha seseorang untuk melakukan jual beli tanpa harus keluar biaya untuk membayar tempat sewa, lalu di bidang pendidikan apalagi di era covid-19 saat ini para murid dan guru diharuskan untuk belajar menggunakan aplikasi seperti Zoom, Google classroom, Google meet dan semacamnya, lalu misal pencarian informasi sangat mudah dikarenakan google ataupun sosial media bahkan tidak jarang kita atau bahkan badan milik negara seperti kepolisian mencari informasi lewat sosial media.

\section{Platform Digital yang Berkembang di Indonesia}

Di Indonesia, platform digital sangat berkembang dan berpengaruh bagi kehidupan masyarakat saat ini, dikutip dari jurnal (De Reuver et al., 2018) platform sosial media seperti Facebook dapat merubah cara orang berinteraksi dan berbagi pengalaman. Begitu pula dengan bisnis ekonomi berbasis platform yang tercipta dengan seiring berkembangnya teknologi yang mengubah mekanisme bisnis konvensional (Setiawan, 2018). Dan dibalik dari perkembangan platform digital juga dipengaruhi oleh teknologi bahasa pemrograman yang semakin canggih, Berikut bahasa pemrograman yang sering digunakan untuk mengembangkan platform digital:

a. Java

Java memiliki banyak kelebihan yang membuat banyak perusahaan memilih java untuk mengembangkannya. Misalnya java bisa diaplikasikan pada beberapa sistem operasi. Selain itu java memiliki Object Oriented Programming. Jadi semua aspek yang ada pada java merupakan objek. Segala tipe data yang diturunkan dari kelas dasar disebut Object dan memudahkan para pemrogram untuk membuat, mendesain, mengembangkan dan memeriksa kesalahan dengan cepat.

Dibandingkan bahasa pemrograman yang lain, java juga memiliki pustaka yang lengkap. Pustaka ini tentu akan memudahkan pemrograman untuk membangun aplikasi. Java digunakan banyak perangkat seperti : Aplikasi desktop seperti acrobat reader, media player, Aplikasi web seperti javatpoint.com, Aplikasi enterprise seperti aplikasi banking, Mobile, Robotik, Game.

b. Python

Python termasuk bahasa tingkat tinggi dalam tingkat bahasa pemrograman. Python juga menjadi salah satu yang dapat membangun aplikasi, baik itu berbasis web ataupun berbasis mobile. Bahasa python juga termasuk ke dalam bahasa pemrograman yang cukup mudah bagi pemula, karena bahasa tersebut mudah untuk dibaca dengan syntax yang mudah untuk dipahami juga.

Banyak perusahan besar yang telah menggunakan Pyhton dalam pengambangan aplikasinya seperti Instagram dan Pinteres. Python juga digunakan oleh para pengembang Google, Yahoo!, dan juga NASA.

c. C

Bahasa pemrograman $\mathrm{C}$ ini dikembangkan dari sekitar tahun 70-an dan cukup populer di Indonesia. Karena hampir sebagian besar perguruan tinggi jurusan IT, ataupun lembaga kursus pemrograman, menggunakan bahasa ini untuk dipelajari pertama kali sebelum mempelajari bahasa yang lain. 
Volume 11 Number 2 November 2021 Page. 1-6

Journal Homepage : http://teknois.stikombinaniaga.ac.id/index.php/JBS

DOI Link : http://doi.org/10.36350/jbs.v11i2

Bahasa $\mathrm{C}$ memiliki struktur bahasa yang baik sehingga pengguna mampu dengan mudah mempelajari dan dapat mudah mengetahui kesalahan dalam membuat suatu program. Bahasa $\mathrm{C}$ menjadi dasar untuk mempelajari bahasa yang lain, karena memang bahasa $\mathrm{C}$ ini merupakan "bapak" dari bahasa pemrograman lain seperti $\mathrm{C \#}, \mathrm{C}++$, dan lain - lain.

\section{KESIMPULAN}

Berdasarkan pada pemaparan pembahasan diatas dapat disimpulkan bahwa platform digital merupakan suatu media yang berbasis digital yang bertujuan untuk memudahkan kehidupan masyarakat saat ini, banyak platform digital yang sering digunakan oleh hampir semua masyarakat. Platform digital digunakan hampir pada semua aspek kehidupan masyarakat saat ini mulai dari berbagi informasi, berjualan atau membeli barang, atau bahkan pendidikan.

Bahasa pemrograman merupakan instruksi standar untuk memerintahkan komputer agar menjalankan fungsi tertentu. Bahasa pemrograman adalah suatu himpunan dari aturan sintaks dan semantik yang dipakai untuk mendefinisikan program komputer. Bahasa ini memungkinkan seseorang programer dapat menentukan secara persis data mana yang akan diolah oleh komputer, bagaimana data ini akan disimpan/diteruskan, dan jenis langkah apa secara persis yang akan diambil dalam berbagai situasi.

Banyak jenis dari bahasa pemrograman itu sendiri contohnya, bahasa $\mathrm{C}$ yang memiliki struktur bahasa yang baik sehingga dapat dipelajari dengan cukup mudah. Bahasa $\mathrm{C}$ juga menjadi dasar untuk mempelajari bahasa pemrograman lain contohnya Bahasa dan $\mathrm{C}++$. Python termasuk dalam bahasa tingkat tinggi namun tetap mudah untuk dipelajari dikarenaka menggunakan syntax yang mudah di ingat, banyak perusahaan besar yang menggunakan bahasa ini untuk mengembangkan platform atau software milik mereka antara lain seperti instagram dan pinterest hingga perusahaan besar seperti Google, Yahoo!, dan juga NASA.

\section{E. DAFTAR PUSTAKA}

[1] Cahyaningtyas, R., \& Iriyani, S. (2015). Perancangan Sistem Informasi Perpustakaan Pada Smp Negeri 3 Tulakan, Kecamatan Tulakan Kabupatean Pacitan. Indonesian Journal on Networking and Security, 4(2), 15-20.

[2] De Reuver, M., Sørensen, C., \& Basole, R. C. (2018). The digital platform: A research agenda. Journal of Information Technology, 33(2), 124-135. https://doi.org/10.1057/s41265-016-0033-3

[3] Hermawan, R., Hidayat, A., \& Utomo, V. G. (2016). Sistem Informasi Penjadwalan Kegiatan Belajar Mengajar Berbasis Web. Evolusi, 4(1), 72-79.

[4] platform @ kbbi.web.id. (n.d.).https://kbbi.web.id/platform

[5] Saragih, richy rotuahta. (2016). Pemrograman dan bahasa Pemrograman. STMIK-STIE Mikroskil, December, 1-91.

[6] Setiawan, A. B. (2018). Revolusi Bisnis Berbasis Platform Sebagai Penggerak Ekonomi Digital Di Indonesia. Masyarakat Telematika Dan Informasi : Jurnal Penelitian Teknologi Informasi Dan Komunikasi, 9(1), 61. https://doi.org/10.17933/mti.v9i1.118 